\title{
Soft Tissue Angiosarcoma
}

National Cancer Institute

\section{Source}

National Cancer Institute. Soft Tissue Angiosarcoma. NCI Thesaurus. Code C121671.

An angiosarcoma that arises from the soft tissues, usually in the deep muscles of the lower extremities, retroperitoneum, mediastinum, and mesentery. 